\title{
コンクリート床下地の表層部品質に関する指標の例示 \\ EXAMPLE OF QUALITY INDEX ON SURFACE LAYER OF CONCRETE GROUND WORK
}

\author{
横山 裕*，横井健** \\ Yutaka YOKOYAMA and Takeshi YOKOI
}

\begin{abstract}
This paper shows a specific example of the quality index along a concept of quality index on the surface layer of concrete ground work, proposed in previous paper.

At first, we limited our object to the flatness and the surface strength of ground work made by normal weight concrete. Then, we made some samples of ground work under a few execution conditions by using several slumps of concrete, and measured their flatness or surface strength by the straightedge method or the scratching method. Finally, we showed relations between the flatness or the surface strength, the slump and the execution condition, as a specific example of the quality index.
\end{abstract}

\section{Keywords : concrete ground work, quality of surface layer, index, flatness, surface strength, execution condition コンクリート床下地, 表層部品質, 指標, 凹凸, 表面強度, 施工条件}

\section{1.はじめに}

床は、建築物内の人閒や什器・備品, 各種機器などが絶えず接し ていることから、日常の安全性, 居住性, 使用性などの観点から重 要な部位といえる。床は、一般に、下地層と、場合によって設けら れる何層かの中間層、および仕上げ層から構成されており、床の性 能には、仕上げ層のみでなく、当然のことながら下地層や中間層が 大きく影響する。多くの場合、下地層 (以降、“床下地”と記す)には コンクリートやそれに類する材料が用いられるが、床下地に用いら れるコンクリートの上面は、型枠などに接している面と異なり、打 設から養生にかけての施工の過程で、通常「ならし」，「押え」などと 称する上面仕上げ作業を施す必要がある。また、養生の際も、より 多くの措置が必要である。そして、これらの作業，措置の良否によっ て床下地の表層部品質は大きく変化することが知られている。

ところが、近年、工期の短縮や工費の削减に伴う労力の低下など の影響で、表層部品質が劣悪な床下地が多く出現しておう、高い性 能を有する中間層, 仕上げ層 (以降、あわせて“仕上げ材”と記す) を選択したにもかかわらず、䇋工後に所期の性能が得られず問題と なる事例が多発している。このような問題を未然に防ぐためには、 床下地の表層部品質と仕上げ材施工後の床の性能との関倸を明確に するとともに、施工の際各作業に費やす労力や養生方法, 期間など の施工条件の要因を取り込んだ床下地の表層部品質に関する指標が
必要と思われる。

このような背景から、前報りでは、上面仕上げ作業担当者や施工 管理担当者を対象とした種々の調查, 実験を行い、床の性能に大き く影響する床下地表層部の品質上の問題点を抽出するとともに、実 際の現場におけるコンクリート床下地の施工条件の実状を把握した。 また、やわらかいフレッシュコンクリートの使用や各作業に費や寸 労力および養生期間の不足などの施工条件の不備が床下地表層部の 品質上の問題点に染く関与していることを明らかにしたうえで、ど のような特性のフレッシュコンクリート(以降、“生コン”と記す)を 用いてどのような条件で施工すればどの程度の表層部品質の床下地 ができるかを定量的に示す指標の必要性を述べた。ただし、前報で は、床下地の表層部品質に関する指標のあり方を概念として述べる に留まっており、このような指標に対する理解を深めるためには、 提案した概念に沿った指標の具体的な姿を例示してゆく必要がある と考えられた。

本報は、前報で提案した床下地の表層部品質に関する指標の具体 例を、コンクリート床下地の施工を模擬した実験結果に基づいて提 示した経過，結果を述べるものである。

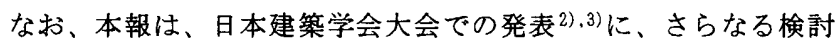
を加えたものである。

\footnotetext{
* 東京工業大学大学院理工学研究科建築学専攻 助教授 $\cdot$ 工博

Assoc. Prof., Dept. of Architecture and Building Eng., Graduate School of Science and Eng., Tokyo Institute of Technology, Dr. Eng. 


\section{2. 研究の目的, 範囲}

図 1 に、前報で提案したコンクリート床下地の表層部品質に関寸 る指標の概念を示す。この指標は、使用する生コンの特性と施工条 件から完成後の床下地の表層部品質を推定したり、逆に床に要求さ れる性能から床下地に要求される表層部品質を設定し、この品質を 具現するために使用す心゙き生コンおよび確保すべき施工条件を合理 的に選定することができるもので、性能の時代における施工に必要 な指標のあり方を示すものといえる。本報は、このような指標の具 体例を提示し、前報で提案した概念に対寸る理解を深めるための一 助とすることを目的とする。

指標の具体例の提示にあたり、当初は、対象とする表層部品質, コンクリートの種類，床下地の工法の範囲をある程度限定するのが 有効と考えられる。本報では、これらの範囲を以下の通り設定した。

・表層部品質は、前報で仕上げ材施工後の床の性能に大きく影響す る品質項目として抽出した凹凸，不陸，表面強度，水分量，ひび 割れのうち、凹凸および表面強度とする。

・ コンクリートの種類は、ごく一般的な普通コンクリート(普通ボ ルトランドセメント，AE減水剤標隻形使用)とする。

・ 床下地の工法は、従来から現場で行われているごく一般的な工法 とする。具体的には、コンクリートポンプなどを用いて生コンを 型枠内に投入し、人力もしくはバイブレータ，機械ごてなどの小 型施工機械にて荒ならし，締固めおよび上面仕上げ作業などを行 う方法とする。

なお、他の表層部品質, コンクリートの種類および床下地の工法 を対象とした検討は、本報以降の課題とする。

以上であるが、本報で提示する指標の例はあくまでも提案した概 念に対する理解を媣めるためのものであること、特に生コンの特性 および施工条件と表層部品質との絶対的関係はあくまでも限られた 条件下での実験で得られたものであり、実際の現場での関係とは必 ずしも一致しないと予想されることを強調する。なお、実際の現場 に直接適用できる実用性のある指標の提示は、本研究での提案に基 づいて多くのデータが蓄積, 整備されることにより達成される課題 と考える。

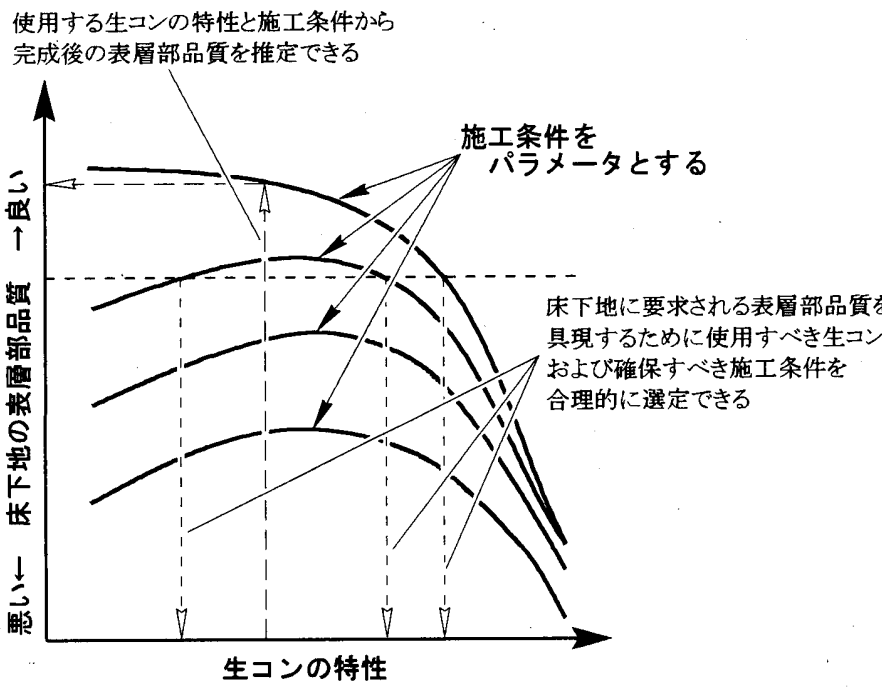

図 1 コンクリート床下地の表層部品質に関する指標の概念

\section{3. 既往の研究}

コンクリート床下地の表層部品質と生コンの特性および施工条件 との関倸に関する既往の研究については、前報で述べている。

また、床下地の表層部品質の測定方法については、これまでに国

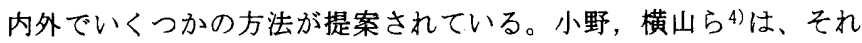
らを含め様々な方法を比較, 検討し、さらに我が国の建築業界の害 状も考慮したうえで、床に携わるすべての業種の関係者間で組織の 規模の大小を問わず共通の言語として用いることができる簡易, 安 価かつ定量的な表層部品質の測定, 評価方法である『コンクリート 床下地表層部の諸品質の測定方法, グレード』を提案している。さ らに、床に関係する様々な立場の実務担当者を対象にアンケート調 查を実施し、提案した測定方法, グレードの妥当性および実用性を 実証している。本報では、4. で述べる通り、表層部品質の測定に小 野，横山ら ${ }^{4)}$ が提案した方法を適用することとする。

なお、関連する既往の研究として、高強度，高流動コンクリート を対象に、床下地の施工に要する土工や土間工の人員数や時間、お よび上面仕上げ作業のしやすさなどを、普通コンクリートと比較す るなどの方法で検討した例がいくつか報告されている例えは55) 8)。ま た、床下地上面仕上げロボット(大型自動機械ごて)などの開発が各 機関でなされた1985〜95年頃に、こての仕様を種々変化させ、コン クリート床下地の表層部品質と生コンの特性との関係を検討した例 がいくつか報告されている例えは99110)ことを、付け加える。

\section{4. 研究方法}

本報の研究方法は、以下の通りである。

(1) 実際の現場における床下地施工時の作業労力や養生方法，期間の 実状を考虑したうえで、コンクリート床下地の施工条件を数段階 設定する。

(2) 実際の現場における構造スラブを模擬した試験体型枠を製作寸 る。次に、製作した型枠と特性の異なる数種の生コンを用い、(1) で設定した施工条件に従って床下地試験体を施工する実験を行 う。

(3) (2)で施工した床下地試験体の凹凸および表面強度を測定する。

(4) (3)で測定した凹凸および表面強度と(2)で使用した生コンの特性と の関係を(1)で設定した施工条件をパラメータとして求め、床下地 の表層部品質に関する指標の具体例として提示する。

以上であるが、(1)の施工条件の設定は、前報で行った実際の現場 におけるコンクリート床下地の施工条件の実状調查結果に基づいて 行うこととする。また、(2)で用いる生コンの特性は、普通コンクリー トの施工性の尺度として最も普及しているスランプを用いて表すこ ととする。さらに、(3)の凹凸および表面強度の測定では、小野, 横 山ら ${ }^{4)}$ が提案した、直定規を用い床下地表面との隙間を測定する方 法、および引掻き試験器を用いて床下地表面につけた傷の幅を測定 する方法を用いることとする。これは、床下地の表層部品質に関す る指標は、実際の現場において、上面仕上げ作業担当者や各種仕上 げ材の製造, 施工担当者、さらには施工管理担当者の間で床下地を 受け渡しする際に活用されるべきものであることから、この指標で 用いる表層部品質を表す尺度は、様々な立場の関係者間で共通の言 語となり得る、簡易かつ安価に測定可能な尺度である必要があるこ とによる。 


\section{5. 凹凸に関する指賗の例示}

\section{1. 床下地試験体施工実験}

\section{1 .1 概要}

床下地試験体施工実験を、以下の要領で行った。

\section{(1) 試験体}

図 2 に、試験体の概要を示す。本試験体は、スラブ厚 $150 \mathrm{~mm} ゙$ 上 端と下端に餅網状配筋 (D10@150mm，かぶり厚 $30 \mathrm{~mm}$ ) が施された、 ごく一般的な構造スラブの一部を模擬したものである。ここで、試 験体の大きさは、約 $1800 \times 550 \mathrm{~mm}$ とした。これは、上面仕上げ作業 で使用するトンボや定規などが支障なく使用できること、施工条件 を制御しやすいよう表面積を $1 \mathrm{~m}^{2}$ とすることに留意し、さらに実験 室の面積上の制約などを考慮して設定したものである。

\section{（2）施工条件}

表 1 に示す通り、生コンの投入方法や各作業に使用できる道具お よび費やすことのできる作業時間などを具体的に規定した、3種の施 工条件を設定した。これらの施工条件は、前報で行った実際の現場 におけるコンクリート床下地の施工条件の実状調查結果(生コン打設 速度，ポンプ1台あたりの作業人員，1人(1時間)あたりの作業面積， 作業手順, 使用できる道具および養生方法, 期間など) と、(1)で述 ぶた試験体の大きさより設定したものである。ここで、I～III の各 条件の意味は、以下の通りである。

I : 上面仕上げ作業担当者が『今まで見聞き，あるいは体験した中 で、最も劣悪だった』という条件(劣悪な条件)
II：上面仕上げ作業担当者および施工管理担当者が『最近ではこの 程度が一般的だ』という条件 (一般的な条件)

III：上面仕上げ作業担当者が『これだけの条件が整えば表層部品質 の良い床下地を施工するのに十分だ』という条件(理想的な条件)

(3) 生コン

表 2 に示す7種の生コンを用いた。これらは、呼び強度を $27 \mathrm{~N} / \mathrm{mm}^{2}$ とし、主に単位水量を変化させることによりかたさを変化させたも のである。

生コンは、プラントより購入し、調合表により調合を確認する一 方、荷降ろしの時点でスランプを測定し、さらに圧縮強度測定用供 試体を必要数採取した。

\section{(4) 作莱担当者}

表 1 に示す各作業のうち、通常土工などが担当する「生コン投入」， 「荒ならし」,「締固め」は、東京工業大学大学院建築学専攻の学生が 行った。また、土間工が担当する「ならし」，「むら直し」，「押え」は、 一釉技能士の資格を持つ熟練上面仕上げ作業担当者 (61歳, 経験年数 45年)が行った。なお、「むら直し」，「押え」の作業に取りかかるタイ ミングの判断も、熟練上面仕上げ作業担当者に一任した。

\subsection{2 経通、結果}

5.1.1で述べた通り、生コン 7 種 $\times$ 施工条件 3 種 $=21$ 種の条件で実験 を行った。実験は、作業担当者を慣机させる目的で事前にリハーサ ルを行ったうえで、2001年10〜 12月に、温度 $20^{\circ} \mathrm{C}$, 湿度 $60 \%$ の恒温 恒湿実験室で行った。実験の際の生コンの提示順序は、作業担当者

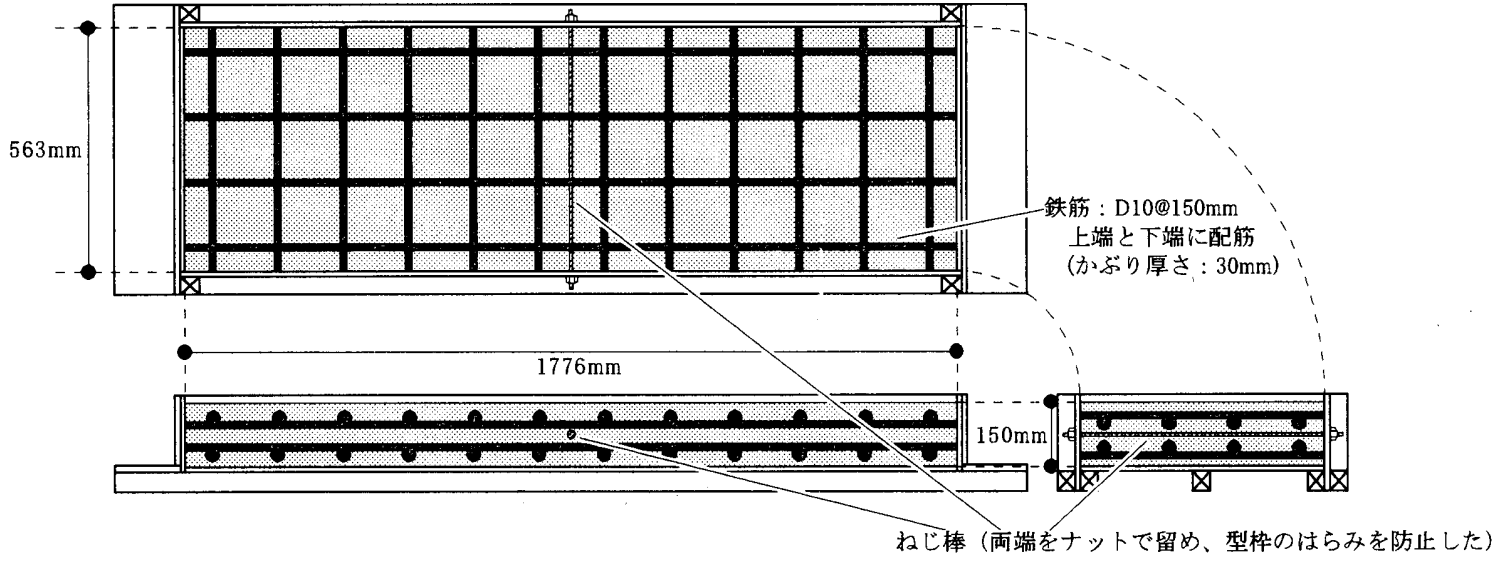

图 2 凹凸に関する実験に用いた試験体の概要

表 1 凹凸に関する実験での施工条件の概要

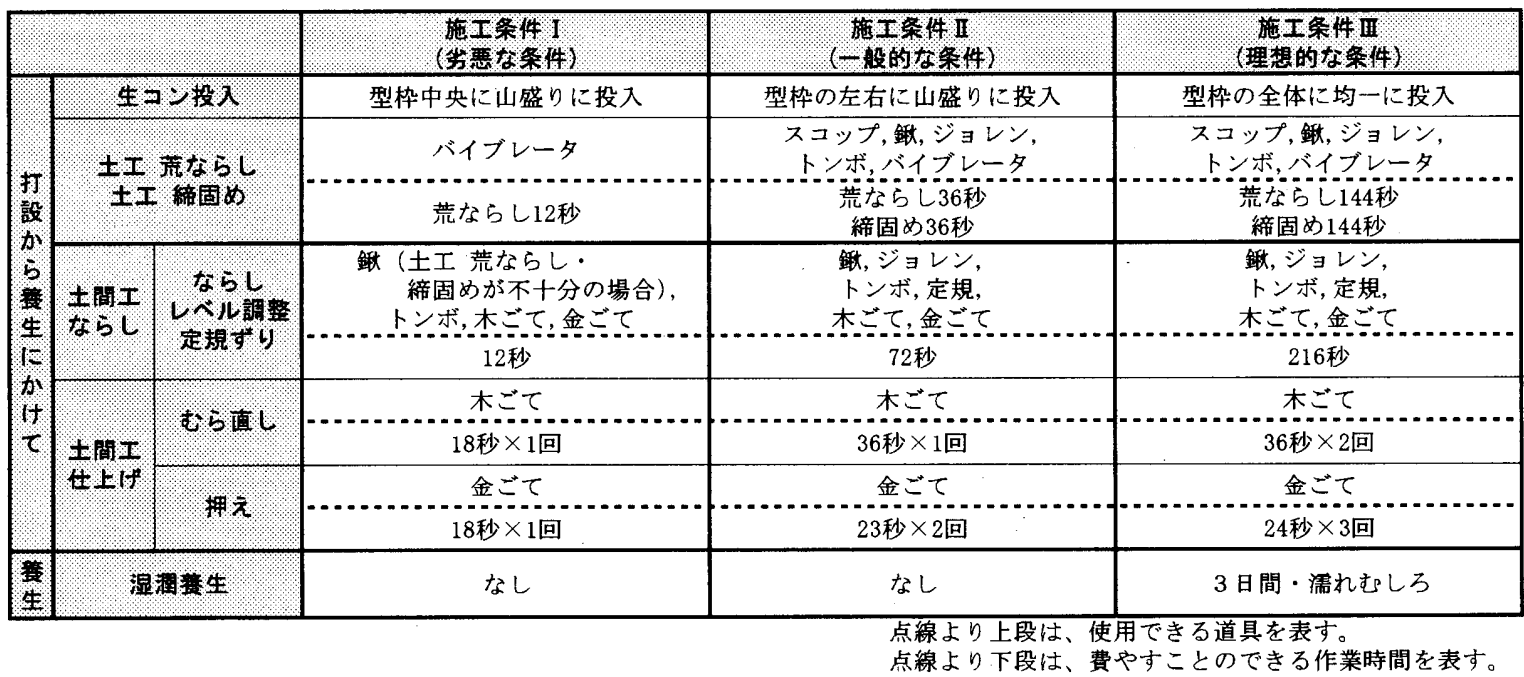


衰 2 凹凸に関する実験で用いた生コンの概要

\begin{tabular}{|c|c|c|c|c|c|c|c|c|c|c|c|c|c|}
\hline \multirow[b]{2}{*}{ 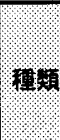 } & \multirow[b]{2}{*}{ (N/mn') } & \multirow[b]{2}{*}{ 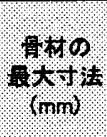 } & \multirow[b]{2}{*}{$\begin{array}{c}\mathrm{l} \\
2 \\
(\mathrm{~cm})\end{array}$} & \multicolumn{7}{|c|}{ 部合 } & \multicolumn{2}{|c|}{ 測定結果 } & \multirow{2}{*}{ 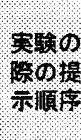 } \\
\hline & & & & 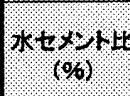 & $\int_{10}(\%)$ & $\int\left(\mathrm{kg} / \mathrm{m}^{3}\right)$ & $\begin{array}{l}t+x / t \\
(k g / n)\end{array}$ & 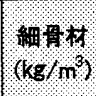 & 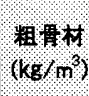 & 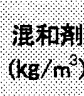 & $\begin{array}{l}\text { スフンフ } \\
(\mathrm{cm}) .\end{array}$ & 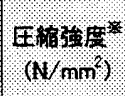 & \\
\hline \multirow{7}{*}{ 普通 } & \multirow{7}{*}{27} & \multirow{7}{*}{20} & 10 & \multirow{7}{*}{54.5} & 43.0 & 160 & 293 & 790 & 1068 & 0.733 & 10.5 & 27.8 & 2 \\
\hline & & & 12 & & 43.8 & 163 & 300 & 799 & 1045 & 0.750 & 13.5 & 29.9 & 7 \\
\hline & & & 15 & & 44.2 & 166 & 304 & 802 & 1032 & 0.760 & 16.2 & 26.6 & 5 \\
\hline & & & 18 & & 45.9 & 176 & 3.23 & 813 & 977 & 0.808 & 19.8 & 25.7 & 6 \\
\hline & & & 20 & & 46.5 & 182 & 334 & 813 & 953 & 0.835 & 21.3 & 29.9 & 4 \\
\hline & & & 21 & & 47.9 & 193 & 354 & 815 & 904 & 0.885 & 22.1 & 27.3 & 1 \\
\hline & & & 24 & & 49.9 & 207 & 380 & 820 & 839 & 0.950 & 24.9 & 25.9 & 3 \\
\hline
\end{tabular}

※ 28日間実験室内封絾養生後に測定

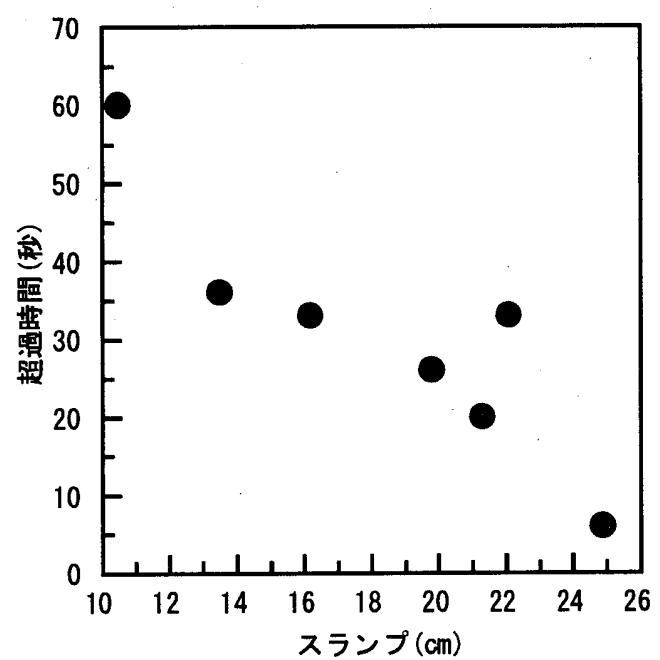

图 3 スランプと施エ条件 I の場合の 「ならし」の作業の超過時間の関係

の熟練度の影響をできる限り取り除く目的で、表 2 に示す通り、生 コンのスランプに対してランダムとした。

ここで、土工の「荒ならし」,「締固め」および土間工の「ならし」,「む ら直し」,「押え」の作業では、所定の時間内に一通りの作業が終了する よう、作業担当者に残り時間を秒読みして知らせた。しかし、施工条 件 Iの場合の「ならし」の作業では、いずれの生コンでも作業時間 が不足したため、所定の作業時間終了後に残った最低限の作業のみ を追加で行わせるとともに、要した時間を超過時間として記録した。

表 2 に、スランプおよび28日間実験室内封縅養生後の圧縮強度の 測定結果を示す。表に示す通り、いずれの生コンでも概ね所定のス ランプおよび圧縮強度が得られていることを確認した。

また、図了に、各生コンのスランプと施工条件 I の場合の「なら し」の作業の超過時間の関倸を示す。図に示す通り、超過時間はス ランプの小さい生コンほど長い傾向があったが、最も長い場合でも 施工条件 Iで規定された作業時間を超えることはなかった。

\section{2. 床下地試験体の山凸の㳔定}

5.1.で施エした床下地試験体の凹凸を、所定の養生期間経過後に 測定した。図4に、床下地試験体の凹凸の測定方法の概要を示す。 具体的には、まず、試験体表面に、図に示す通り3本の測定線を設定 した。次に、3本のうち一つの測定線上に直定規を置き、試験体表面

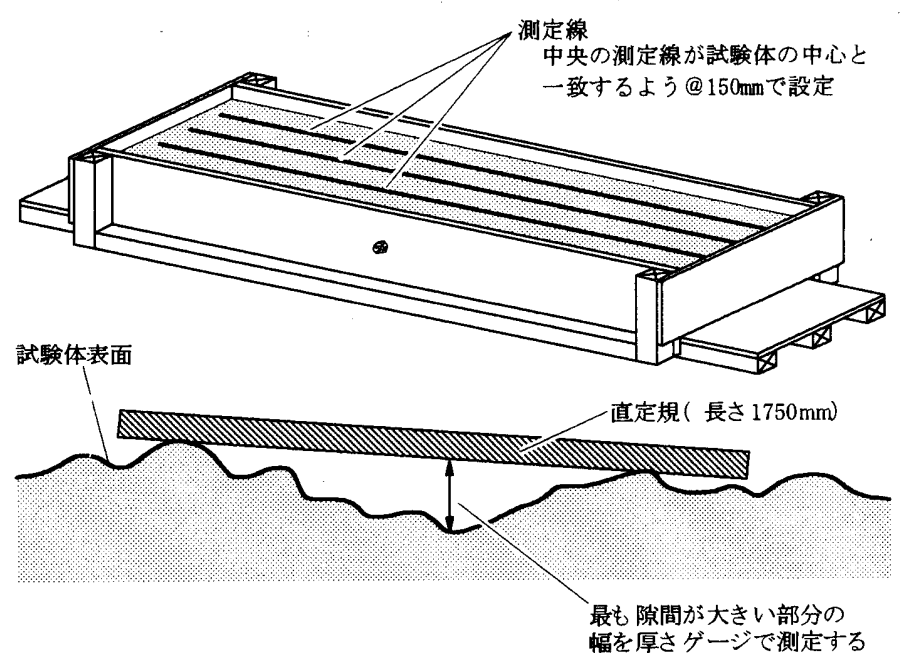

図4 床下地試験体の凹凸の測定方法の概要

との間の隙間を直定規全体に渡って観察するとともに、厚さゲージ を用いて隙間の幅を適宜測定し、最も大きい值を記録した。この作 業を他の測定線でも同様に行い、3本の各測定線での結果の平均を、 各試験体の凹凸を表す “最大隙間”として求めた。ただし、直定規 の長さは、小野, 横山ら 4 )の提案では $2000 \mathrm{~mm}$ となっているが、本報 では、試験体の大きさによる制限より $1750 \mathrm{~mm}$ とした。

\section{3. 凹凸に関する指檈の例示}

図 5 に、最大隙間とスランプの関係を、施工条件をパラメータと して示す。ただし、施工条件 I の場合、図了に示した通り、スラン プ10. $5 \mathrm{~cm}$ と $24.9 \mathrm{~cm}$ の生コンでは超過時閒が他と著しく異なり、同一 の施工条件とはみなしがたいことから、これらの結果は最大隙間と スランプの関係に関する考察対象から除外することとし、図5では 他と異なる記号(つ)で示した。なお、図の綐軸は、上の方が品質が 良い(最大隙閒が小さい)ことを表すよう表示してある。また、図中 の点線は、対応の中心傾向を示す曲線であり、目視で描いたもので ある。

図より、以下の事項が考察できる。

，最大隙間の序列には、スランプの大小に関わらず、施工条件の良 否が明確に反映されている。すなわち、最大隙間は、施工条件吕 が最も小さく、続いてIIで、I が最も大きくなっている。また、 最大隙間の差は、施工条吽 I とII の間で特に大きくなっている。 


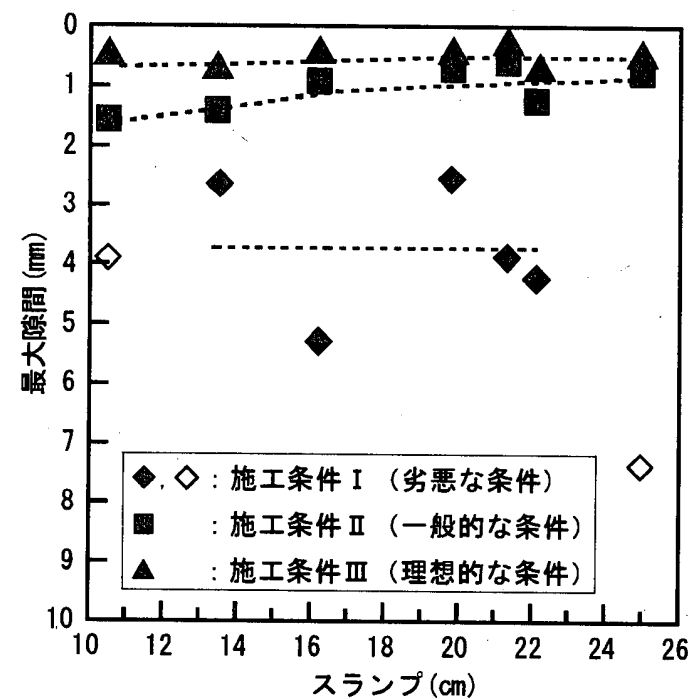

図 5 最大隙間とスランプの関係 (凹凸に関する指標の具体例)

施エ条件正では、スランプの違いによる最大隙間の変化は小さく なっている。このことは、施工条件が十分であれば、かたい生コ ンでも凹凸なく施工できることを意味している。

・施工条件 II では、スランプが小さいほど最大隙間が大きくなって いる。すなわち、現在実際の現場で一般的な程度の施工条件では、 生コンのかたさが凹凸に影響し、かたい生コンでは凹凸が大きく なることがわかる。

・施工条件 I では、スランプ13.5 22. $1 \mathrm{~cm}$ の範囲で最大隙間とス ランプの間に明確な傾向は見られない。これは、生コンのかたさ の違いが凹凸にほとんど反映されないほど、施工条件が不十分で あることによるものと思われる。

以上に述べたように、図 5 には、生コンの特性および施工条件が 凹凸に反映される様子が具体的，定量的に示されていることから、 前報で提案した概念を具体化した例として十分有効と考える。よっ て、図 5 を、コンクリート床下地の凹凸に関する指標の具体例とし て提示する。

なお、施エ条件 I のスランプ $24.9 \mathrm{~cm}$ 生コンでは、最大隙間が他 と比較して著しく大きくなっているが、これは、土間工の「ならし」
の際、作業時間の制約からこてのみしか用いることができず、かつ 急いで作業したため、やわらかい生コンでは中央部をえぐり取って しまったことによるものと思われる。

\section{6. 表面強度に関する指檈の例示 \\ 6. 1. 床下地試験体施工実験 \\ 6.1.1 概要}

床下地試験体施工実験を、以下の要領で行った。

\section{(1) 試験体}

図 6 に、試験体の概要を示す。本試験体も、ごく一般的な構造ス ラブの一部を模擬したものであるが、試験体の大きさは、凹凸の場 合のように特に大きな試験体は必要ないことから、養生の際の温湿 度管理の都合を考慮し、550mm角とした。なお、表面強度には配筋 の影響は少ないと想定されたことから、配筋は施さないこととした。 (2) 施工条件

5.1.1の (2)で述べたと同様の要領で、表 3に示す3種の施工条件を 設定した。

(3) 生コン

表 4 に示す4種の生コンを用いた。これらは、呼び強度を $27 \mathrm{~N} / \mathrm{mm}^{2}$ とし、主に単位水量を変化させることによりかたさを変化させたも のである。

生コンは、実験室で混練し、練り上がり時にスランプを測定する とともに、圧縮強度測定用供試体を必要数採取した。

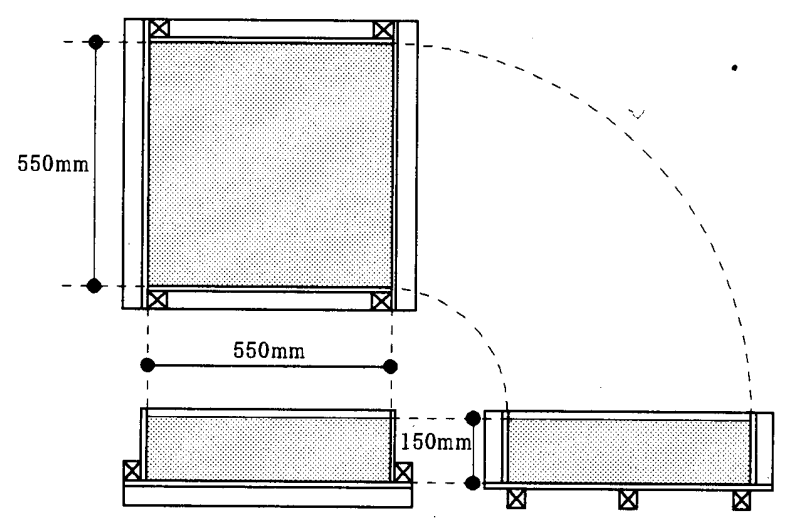

図6表面強度に関する英験で用いた試験体の概要

表 3 表面強度に関する実験での施エ条件の概要

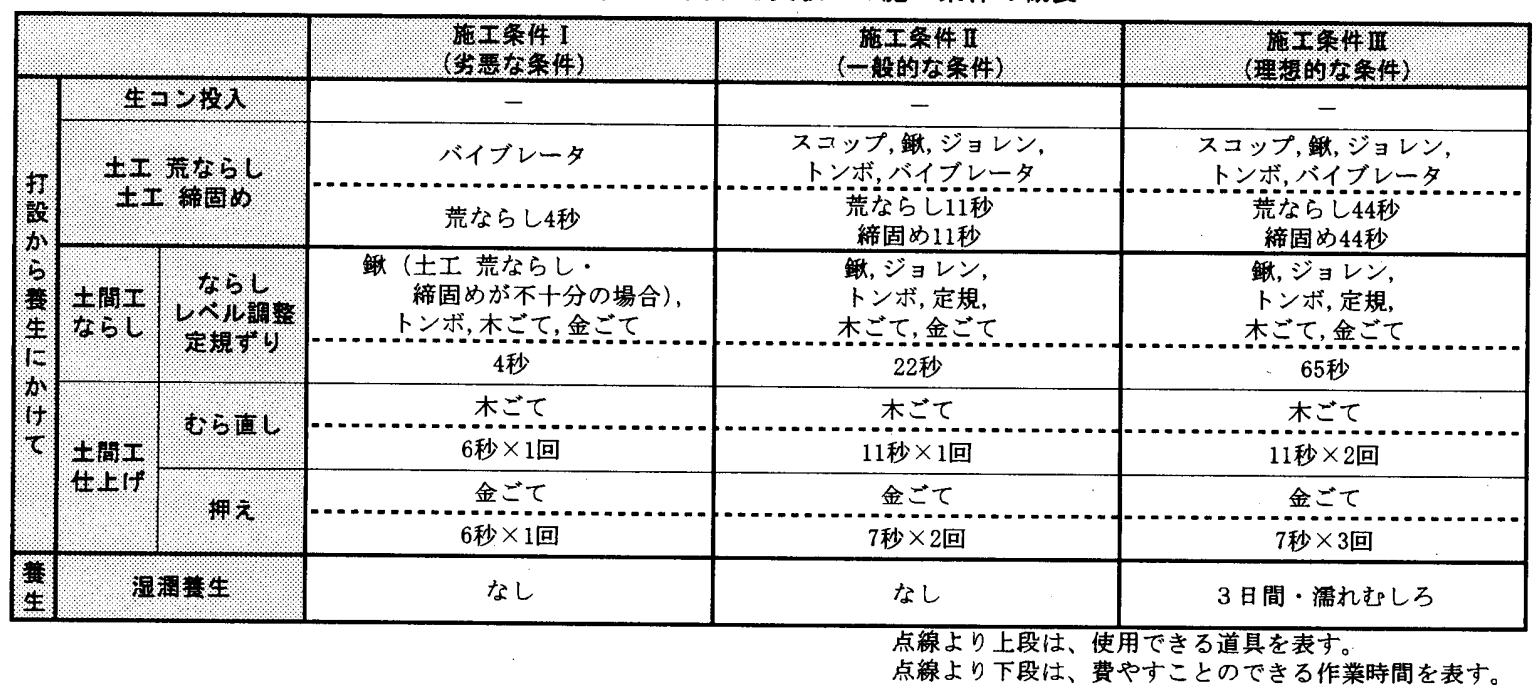


表 4 表面強度に関する実験で用いた生コンの概要

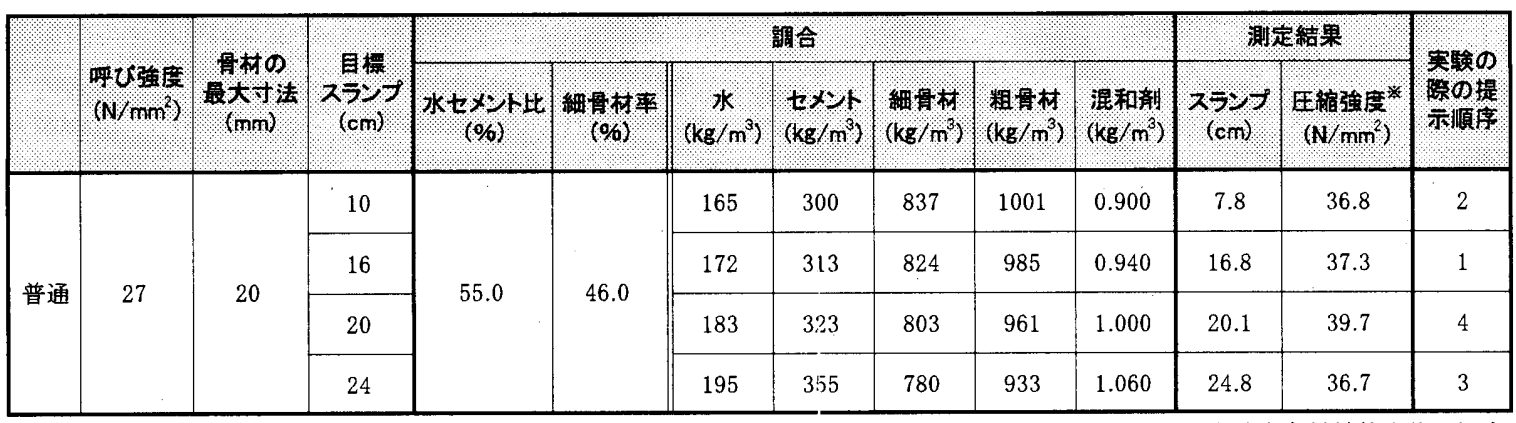

※ 28日間実験室内封絾盖生後に測定

\section{（4）作業担当者}

「荒ならし」、「締固め」は東京工業大学大学院建築学専攻の学生が 行い、「ならし」，「むら直し」，「押え」は一級技能士の資格を持つ熟 練上面仕上げ作業担当者 (58歳, 経験年数 34 年) が行った。なお、「む ら直し」，「押え」の作業に取りかかるタイミングの判断も、熟練上面 仕上げ作業担当者に一任した。

\subsection{2 経過, 結果}

6.1.1で述べた通り、生コン 4 種 $\times$ 施工条件 3 種 $=12$ 種の条件で実験 を行った。実験は、5.1.2で述べたと同様の要領で、リハーサルの後、 2002年8〜10月に行った。実験の際の生コンの提示順序は、表 4 に示 寸通りである。なお、本実験では、いずれの生コン，施工条件の組 み合わせでも、作業時間が不足することはなかった。

表 4 に、スランプと28日閒封縅養生後の圧縮強度の測定結果を示 す。表に示す通り、いずれの生コンでも所定のスランプ，圧縮強度 が得られていることを確認した。

\section{2. 床下地試験体の表面強度の測定}

6.1.で施工した床下地試験体を、表 $3 に$ 示した条件に従って温度 $20^{\circ} \mathrm{C}$, 湿度 $60 \%$ の恒温恒湿実験室で 28 日間養生した後、表面強度を 測定した。具体的には、日本建築仕上学会式引择き試験器を用い、 この試験器に加圧力 $1.0 \mathrm{kgf}(9.8 \mathrm{~N})$ の針を取り付けたうえで試験体表 面を引择き、ついた傷の幅をクラックスケールを用いて測定した。 ここで、引掻く際の速さは $2 \mathrm{~cm} / \mathrm{s}$ 程度とし、試験器に定規をあてがっ て長さ $10 \mathrm{~cm}$ 程度引掻くこととした。測定は、一つの試験体について 複数回行い、平均的な值を求めた。ただし、施工条件 I のスランプ $7.8 \mathrm{~cm}$ の生コンでは、試験体の表面全体に細かい凹凸があるため引 掻き傷を適切につけることができず、傷幅を求めることはできなかっ た。

\section{3. 表面強度に関する指標の例示}

図 7 に、傷幅とスランプとの関倸を、施工条件をパラメータとし て示す。なお、図の縦軸は、上の方が品質が良い(傷幅が小さい)こ とを表すよう表示してある。また、図中の点線は、対応の中心傾向 を示寸曲線であり、目視で描いたものである。

図より、以下の事項が考察できる。

・傷幅の序列には、スランプの大小に関わらず、施工条件の良否が 明確に反映されている。すなわち、傷幅は、施工条件正が最も小 さく、続いて IIで、I が最も大きくなっている。

・水セメント比が一定の生コンを用いたにもかかわらず、施工条件 正では、スランプが大きい範囲で傷幅が大きくなっている。これ に対し、スランプが小さい範囲では、傷幅はほとんど変化してい

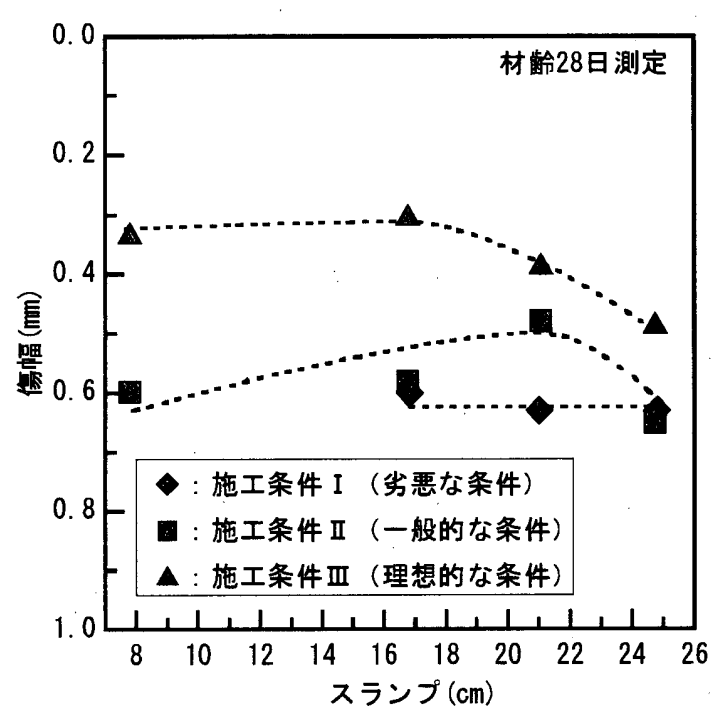

図 7 傷幅とスランプの関係 （表面強度に関する指標の具体例）

ない。一方、施工条件 II では、傷幅が最も小さくなるスランプが 存在し、それよりスランプが大きくても小さくても傷幅が大きく なっている。ここで、やわらかい生コンで傷幅が大きくなるのは、 余剩水が多いために表面が粗になったり、表面の水セメント比が 局部的に大きくなるなどの影響で、表面強度が低下することによ るものと思われる。一方、施工条件 II 場合、かたい生コンでも 傷幅が大きくなっているが、これは、生コンのかたさに対して施 工条件が不十分なため、上面仕上げ作業を通じて表面を強くする ことが十分にできないことによるものと思われる。これに対し、 十分な施工条件が確保されている施工条件而では、かたい生コン でも、表面強度はほ上んど低下していない。

・施工条件 I では、スランプ16.8 24.8cmの範囲で傷幅とスラン プの間に明確な傾向は見られない。これは、生コンのかたさの違 いが表面強度にほとんど反映されないほど、施工条件が不十分で あることによるものと思われる。

以上に述べたように、図7には、生コンの特性と施工条件が表面 強度に反映される様子が具体的，定量的に示されていることから、 前報で提案した概念を具体化した例として十分有効と考える。よっ て、図7を、コンクリート床下地の表面強度に関する指標の具体例 として提示する。

\section{7. おわりに}

床下地の表層部品質に関する指標の具体例を提示し、前報で提案 
した概念に対する理解を深めるための一助とすることを目的とした 本研究の結論は、以下の通りである。

ごく一般的な普通コンクリートを用い、実際の玩場におけるコン クリート床下地の施工を模擬した実験を行った結果に基づいて、生 コンの特性および施工条件と、仕上げ材施工後の床の性能に大きく 影響する品質項目の一つである凹凸および表面強度との関係を、定 量的に提示した。ここで、生コンの特性は、普通コンクリートの施 工性の尺度として最も普及しているスランプを用いて表した。また、 施工条件は、前報での実状調査結果に基づいて、実際の現場におけ る床下地施工時の作業労力や養生方法，期間などとの関倸付けがで きるよう設定した。一方、凹凸および表面強度の測定には、様々な 立場の関係者間で共通の言語となり得る簡易で安価に測定できる方 法として設定された、直定規を用い床下地表面との隙間を測定する 方法、および引择き試験器を用いて床下地表面につけた傷の幅を測 定する方法を用いた。このように、本報で提示した指標には、生コ ンの特性および施工条件が凹凸および表面強度に反映される様子が、 実際の現場で活用しや寸い尺度を用いて具体的, 定量的に示されて いる。加えて、現在一般的な程度の施工条件ではかたい生コンを用 いた場合凹凸が大きくかつ表面強度が低くなるが十分な施工条件を 確保すればかたい生コンでも凹凹なく施工できから高い表面強度が 得られる、施工条件が不十分な場合は生コンのかたさの如何に関わ らず凹凸は大きくかつ表面强度は低くなる、などの実践的な示唆も 含まれており、前報で提案した概念を具体化した例として十分意味 あるものといえる。

以上であるが、本報で例示した指標はあくまでも限られた条件下 での実験で得られた一例であり、2.で述べた通り、指標に示された 数值の絶対的関倸は害際の現場での関係とは必ずしも一致しないと 予想されることを重称て強調する。なお、今後は、対象とする表層部 品質, コンクリートの種類および床下地の工法の範囲を広げた検討 を行い、より汎用性，一般性の高い指標の提示を試みる予定である。

\section{謝辞}

本研究のテーマ設定や方向付けなどにあたり種々御指導いただい た小野英哲先生 (東北工業大学教授, 東京工業大学名誉教授・工博) に、厚く御礼申し上げます。また、本研究に対し有益な御助言をい ただきました、梶浦茂男部会長, 中丸 清氏をはじめとする日本床施 工技術研究協議会第一部会の皆様、実験に御協力いただきました木 下昌澄氏，中丸幹雄氏に哚く謝意を表します。

\section{参考文南}

11 横山 裕, 横井 煡: コンクリート床下地の表層部品質に関する指標のあ り方，日本建築学会構造系論文集，第580号，pp. 15２2，2004.6

2) 横山裕, 横井 健: コンクリート床の品質とフレッシュコンクリートの 特性および施工条件の関倸 (その3)施工条件の赛態調查および表面凹凸 の镅点からの検討, 日本建筮学会大会学術講演梗概集, A-1, pp. 629 630, 2003. 9

3）横山裕, 森 剛平, 横井 健: コンクリート床の品質とフレッシュコンク リートの特性および施工条件の関保 (その 4 ) 表面強度および水分量の観 点加の検討, 日本建筑学会大会学術講演梗概集, A-1, pp. 631〜 632, 2003. 9

4) 小野英哲, 横山裕, 永橋 進, 梶浦茂男, 横井 健, 湯浅昇, 端 直人, 小俣一夫 : コンクリート本下地表首部の諸品質の简易测定,評価方法の提 案， 日本建筑学会技術報告集，第18号，pp. 11 16，2003. 12

5）早川光敬，友澤史紀，清水昭之，浜田 勝，小野山貫造，杉本 貢，下山 善秀 : 各種高流動コンクリートの特性評価および実大模型打設実験（そ の 6 実大模型打設実験の施工性、流動性・充填性の検討)，日本建築学 会大会学術满演梗概集A-1，pp. 1155～1156，1993.9

6) 久保田昌吾, 中根 淳, 川上栄一：RC超高層コンクリートに関する研究 (その 20 高強度コンクリートを用いた床スラブのこて仕上げに関する 検郡)，日本建築学会大会学術講演梗概集A-1，pp. 269〜270，1994. 9

7）佐原晴也，竹下治之: 高流動コンクリート適用時のスラブ上面の仕上げ方 法の検吋, 日本建築学会大会学術講演梗概集A-1, pp. 587〜 588，1994.9

8）推原大和, 本田悟：暑中噮境下における高流動コンクリートを用いた床 スラブの諸性状に関する研究（その1。床仕上げ作業性），日本建築学会 大会学術講演梗概集A-1， pp. 487〜 488, 1995.8

9）三上貴正，荒川㙇也，小野英哲：コンクリート直仕上げ床の仕上がりに 及ぼす機械ごての仕様およびュンクリート性状の影響の考察，日本建筑 学会構造系論文報告集, 第453号, pp. 27〜37, 1993.11

10）三上貴正，早野博幸，小野英哲：機械ごてによるコンクリート直仕上げ 床の施工条件判定のためのコンクリート性状の㨽定方法に関する研究， 日本建筑学会構造系論文報告集，第465号，pp. 11 18，1994. 11

(2004年 4 月 10 日原稿受理，2004年 9 月 8 日採用決定) 